\title{
DIMENSIONS OF THE POLITICAL IN ADJUDICATION: A CASE STUDY
}

\begin{abstract}
Contrary to traditional accounts, which treat adjudication as the application of legal norms to the facts of a case, without any creative activity, the present paper assumes, following crtitical legal theory, that adjudication as a social practice belongs to the sphere of the political and involves judicial decision-making. The concept of the political is understood, following Chantal Mouffe, as the dimension of unalienable and inherent antagonism underlying any society. Any judicial decision, and especially one taken in a case where the court enjoyed a broad scope of discretion, influences a given social antagonism. However, as a prerequisite of a critical analysis of case-law it is necessary to identify the social antagonisms in question. To this end, the paper first analyses the very concept of an antagonism, highlighting its collective character, and then makes a tentative application of the concept to the European Court of Justice, attempting to identify the main types of social antagonisms which are subject to the Court's jurisdiction.
\end{abstract}

Keywords: adjudication, the political, European Court of Justice.

\section{INTRODUCTION: THE POLITICAL AS A DIMENSION OF ADJUDICATION}

In traditional positivistic narratives, adjudication is perceived as the application of law in an individual and concrete case. In this perspective, the court is seen as a body which interprets the general and abstract legal norms and, on the basis of this interpretation, creates an individual and concrete legal norm for a given case, applying the general norm in casu, but it does not create the law (see e.g. SN I CSK 59/12). This narrative, however, tells, at the very most, only part of the story. Specifically, what it overlooks, is the fact that courts usually enjoy a more less extensive scope of discretion when interpreting the general and abstract legal materials (Kennedy 2008; Mańko 2018a; Mańko 2018b, 95-146). Within that discretion, they can (and indeed: have to) choose between different legal outcomes of the case or, to put it in different words, they are faced with alternative interpretive options to choose from (Mańko, forthcoming). This is especially true of highest courts, such as supreme courts, constitutional courts,

*University of Wrocław, Centre for Legal Education and Social Theory, rafal.manko@prawo. uni.wroc.pl.

All views expressed in this paper are personal to the Author and do not reflect the position of any institution. 
high administrative courts or supranational courts, which often combine the functions of constitutional, administrative and supreme courts. Judges and conventional legal theorists often tend to downplay the aspect of choice, either claiming that there is, allegedly, an objectively correct "one right answer" which can be discovered (e.g. Dworkin 1977, 36), or, if they do admit the plurality of interpretive options, they nonetheless tend to overestimate the role and importance of legal arguments, such as those based on proportionality, balancing or coherence (with earlier case-law) in the choice made.

Critical legal theory, in contrast, rejects this view, drawing attention to the judge's freedom of choice, which, ultimately, depends on the amount of legal work that needs to be done (Kennedy 2008, 165). This is not to say that there are absolutely no limits to the discretional power of judges and that "anything goes" as long as a judge signs it as his or her judgment. Such a nihilist approach would overlook the role played by legal culture in limiting the judge's freedom of choice. And yet, this same legal culture fails to limit his or her choices absolutely. At the end of the day, especially in a case which is novel ("case of first impression") or "hard" (either prima facie or through the the amount of legal work expended), a judge is faced with a certain choice, which - even if limited to those possible legal interpretations which are plausible under a given legal culture - still requires a decision to be made.

Such a decision can be made taking various factors into account. Judges will often look to the relative "quality" of legal arguments behind each option or into the consistency of the solutions with earlier case law, or with the values imputed to the law-maker, or with whatever "purpose" they like to see in the legal rule or institution or doctrine they are asked to interpret. All this is the daily bread of judges and part of their social craft, and arguments of this kind can be found in any more elaborate judicial decision, especially in a "hard" case. And yet, as I claim, all these aspects - let me call them formal or even formalist - tell only part of the story. The other part of the story - let me call it substantive - is, at least from the point of view of nonlawyers, much more important. Of course, this other part of the story does come into play especially in "pragmatist" or "anti-formalist" legal cultures. The usus modernus paid attention to the "consuetudines hodiernae", private lawyers are used to speaking about the "needs of commerce", and public lawyers have their own catchphrases such as "public interest", "raison d'état" or "ordre public". True, all such devices - be they general clauses or other open norms, or simply the admittance of "non-formalist" or "pragmatist" argumentation in courts - do open up the formal structure of the juridical to voices coming from beyond its remits (cf. Gray 2003). And yet, I insist that this is still part of the story, doubtless more important than the formalist talk of "coherence" or "quality of legal arguments" or "balancing", but still not touching the law's Real, still moving somewhere between its Symbolic and Imaginary. ${ }^{1}$

${ }^{1}$ I am using the notions of Real, Symbolic and Imaginary (RSI) in the Lacanian sense. See Lacan 1998 [1975]. The Symbolic order denotes the objective and supraindividual reality of culture 
This is because law's Real is precisely there, where its symbolising powers cease, where it cannot find the language to describe what is at stake. The law's Real is the political (Mańko 2008c, 33) understood as the dimension of antagonism inherent in any society (Mouffe 2005). True, law was born not from harmony, but from conflict (Pashukanis 1983, 81), and not from agreement, but from the need to resolve actual disputes (Kojève 2007, 173-174). And yet, law insists on the individual dimension of the conflict, and, beyond that, on coherence, perhaps justice and fairness, but not on the essential conflictual dimension which is inherent in any society. Or at least this is the picture of law that we can reconstruct when reading judgments.

A properly critical reading of case-law presupposes, then, to align it with the existing conflicts in society, and to read cases not only against legal texts and earlier cases, but above all against the background of conflicts they impact. By conflict I mean here not the individual conflict between litigants, which is plainly visible and hardly difficult to decipher; I mean here proper antagonisms, i.e. collective conflicts, conflicts between classes, social groups and other collectivities (Mańko 2008a, 67-68, 70, 86), or, to put it in other words, subjectivities. ${ }^{2}$ Judges, especially those more enlightened, and especially those sitting on higher courts, including supranational ones, are - I assume - pretty aware that their decision will have an impact upon such on-going antagonisms. They know that if they decide a consumer case, such as Dziubak (ECJ C-260/18), this will affect thousands, if not millions, other consumers who were lured into Swiss frank loans; they know that if they decide a labour case, such as Alemo-Herron (ECJ C-426/11), this will likewise affect thousands of workers who had the misfortune of having their enterprise transferred from the public to the private sector. And yet, this collective dimension is not present in the legal reasoning that we are given to read, and - more suprisingly - is hardly present in case-law comments. What is more, the alternative interpretations - all those which were conceivable under a given legal culture but were explicitly or implicitly rejected - are not systematically discussed in case-notes, let alone in judgments. The approach advocated in this paper rests on the assumption of judicial decisionism, rooted in the concept of indeterminacy of the law. A judicial decision, especially of a highest court, and

which precedes individuality; the Imaginary denotes the subject's self-identification; the Real is that what escapes symbolisati on (is not covered by the Symbolic order). The RSI triade is often used to conceptualise social and cultural phenomena, providing a language in which to capture the role of ideology (Symbolic order) vis-à-vis those aspects of social life which are hidden, masked and repressed (the Real).

${ }^{2}$ Speaking of consumers vs. traders, or workers vs. employees, we are in fact denoting certain abstract forms of (legal and economic) subjectivity, and each individual act of litigaiton (between a concrete worker and a concrete employer) is always already also an act of a 'collective' dispute between workers (in the abstract) and employers (in the abstract). I would like to thank Dr Gian Giacomo Fusco for suggesting me the idea of using the notion of a 'subjectivity' in the context of my research. 
especially if varios interpretations were possible is, therefore, at least to a certain extent, a 'sovereign decision [...] which is not deducible from a pre-existing norm, or from a higher authority: it establishes the law ex nihilo, becoming in this sense absolute' (Fusco 2017, 134). ${ }^{3}$

With this paper, I hope to make a step towards remedying this situation and contributing to a shift of the discursive attitude of legal commentators and, more importantly, hopefully also that of judges. If we take the political seriously, both judges and legal commentators should, for every case which can be seen as controversial in its policy dimension, seek to identify, first of all, the dimension of antagonism that was at stake in the case and, secondly, to enumerate all the possible intepretive options the court faced (or could have faced with more legal work), analysing how these could have impacted the antagonism in question.

For this purpose, I will resort to a case study and make a first attempt at bringing together all the dimensions of antagonism that fall within the jurisdiction of the European Court of Justice (ECJ). The choice of the ECJ as an object of a case study is justified by various factors, in particular its authoritative role in the interpretation of EU law and its impact upon the legal life of the Member States. The identification of the dimensions of the political, i.e. social antagonisms, should be seen as a first step towards building a comprehensive methodology of critical analysis of case-law. As such, it is indispensable for such a methodology, because without knowing what conflicts exactly are at stake it is impossible to evaluate the possibile intepretive alternatives against any workable benchmark.

\section{IDENTIFYING ANTAGONISMS IN ADJUDICATION}

Until now, I was referring to antagonisms as if their identification was straightforward. Often it is. In a case as Dziubak, where consumers are suing the bank which lured them into a foreign currency loan it is clear that the antagonism at stake is between consumers and the banking sector, or more broadly - between consumers and businesses. Likewide, in a case like Alemo-Herron, where a worker is suing his employer who refuses to respect a collective agreement, although it is binding by virtue of the contract, it is also clear: the class antagonism of workers vs. the capital is at stake. But things can get more complicated. In Laval (ECJ C-341/05) the obvious antagonism is that between workers (trade unions) and the capital, but Damjan Kukovec insists that a hidden antagonism between Central European workers (from the periphery) and Western European workers (from the

${ }^{3}$ This is in line with Schmitt's assertion contra Kelsen that in law 'there are elements that are not deducible from norms. Not only the exception but also decisions, that are fundamental principles of legal systems, are, for Schmitt, not deducible entirely from norms. In every legal decision, there is a fissure, an aperture, thanks to which, it is never possible to derive a decision in its entirety through the formal contents of norms' (Fusco 2017, 134). Cf. Schmitt $(2005,31)$. 
core) is also at stake (Kukovec 2014). And what about cases like Białowieża (ECJ C-441/17), Celmer (ECJ C-216/18 PPU) or $A K$ (ECJ C-585/18) - do they all pertain to a certain antagonism? Or is it possible that in some cases, despite the Court's extensive discretional power, no antagonism is really at stake?

To answer such questions it becomes necessary to define the notion of antagonism. I have hinted above at the assumption that for an antagonism to be treated as part of the political, it should have a collective character. And yet, sociology defines a "social group" as a collectivity of... at least three people (Hansen, Rapley 2006, 256). In this sense, taking into account that litigants usually have families or are part of other "social groups", practically every litigation would have a "social group" interested in its outcome (say, the litigant's spouse and child, or his or her two close friends, amounting to three people in total). Does this mean that such litigation is really part of a certain social antagonism? Obviously, such an approach would miss the goal of identifying antagonisms in adjudciation. A different, more adequate definition needs to be sought after.

Definitely, class antagonisms (of an economic nature) are at the core of the proposed definition. In legal terms, they usually appear in two situations: firstly, in the workplace, where the object of the struggle is the amount of work demanded from the worker measured against the pay and conditions of employment (including, but not limited to, its stability); and, secondly, outside the workplace, where the actual value of the salary obtained from the employer is determined, firstly by the level of prices, but also by the level of quality and the legal assurances offered to the worker in his guise as a "consumer". Of course, the notion of consumer, as any other legal notion, has in itself a quantum of artificiality, and most notably consumers may be, in certain situations, in an economically privileged position in contrast to the "traders" they contract with (e.g. when a small enterpreneur who offers a good or service to a rich consumer). Nonetheless, such exceptions apart, it can be said, with a large degree of certitude, that the legal figures of consumer/employee, on one hand, and trader/business/ employer, on the other hand, do coincide, by and large, with the fundamental class antagonism present in every society. Hence their crucial importance for the identification of antagonisms in adjudication.

However, social antagonisms are not only of a class character. There are also social groups that cannot be identified as classes, such as lawyers or doctors, who struggle for their interests, for instance with regard to access to their regulated professions, or, with regard to judges, to maintain their independence and financial standing. Furthermore, there are minority groups, such as ethnic or sexual or religious minorities, which seek to stand up for their rights. And finally, there are conflicts of a more ideological or symbolic character, where the stakes are nonetheless subjectively important to their participants, often having a direct influence upon their dignity or health or even basic personal freedom, such as struggles concerning reproductive rights or the scope of the freedom of speech. 
True, such ideological struggles are much more likely to end up in the European Court of Human Rights than before the ECJ, nonetheless they do occur and any tentative typology of dimensions of the political must also take them into account.

\section{A TENTATIVE ATTEMPT AT IDENTIFIYNIG THE DIMENSIONS OF THE POLITICAL BEFORE THE ECJ}

As I indicated above, the protypical antagonism is a class antagonism. Hence, the disputes involving, on one hand, workers and employers, and, on the other hand, consumers and businesses, will belong to the core of the dimensions of antagonism decided upon by the Court. As regards employment law, the appropriate legal basis is to be found in Article 153 TFEU, which has been the basis of the adoption of a whole series of directives: on working time (2003/88), written form of employment conditions (1991/533), part-time work (1997/81), fixedtime work (1999/70), employees' rights in the event of transfers of undertakings (2001/23), temporary employment (2008/104), and parental leave (2010/18). The judicial interpretation of each of these directives involves deciding on the workercapital antagonism. Such decisions as Alemo-Herron or Laval mentioned above, or more recent ones, such as Asklepios (ECJ C-680/15) or AGET Iraklis (ECJ C-201/15), are taken within a certain margin of discretionary power, and their outcomes impact upon the on-going class antagonism in a very direct manner.

The other juridical facet of the class antagonism is, as indicated above, the consumer vs. business antagonism which ultimately makes the same parties meet, but this time "after hours". The legal basis of EU consumer law has been Article 114 TFEU, and the corpus of directives is equally broad as the one concerning labour law, including inter alia directives on unfair contractual terms (93/13), distance marketing of consumer financial services $(2002 / 65)$, consumer credit (2008/48), consumer rights (2011/83), timeshare (2008/122), package travel (2015/2302), consumer sales (2019/771) and supply of digital content (2019/770). Cases, in which the Court interprets those directives are, as a rule, concerned with an actual antagonism between consumers and businesses. The more the interpretation is favourable to the consumer, the less favourable it is to the business, and vice versa. I will illustrate this aspect in the next section where I focus on a case study based on the Dziubak case.

A third important area in which the Court's rulings have a direct socioeconomic impact are competition cases. Here, in legal terms the litigants are the Commission (as author of an anti-trust decision) and the enterprise concerned, but it is obvious that the decisions have a broad societal impact, including not only prices for consumers, but also food safety and climate protection (Šmejkal 2015; Lehaire 2016; Ezrachi 2018; Senn 2019). Given that one side of the balance are consumers, their safety, welfare and well-being, and on the other hand the 
profit of multinational companies, the class character of the antagonism is well visible. A good example is the Courage case (ECJ C-453/99) in which, as Lehaire puts it, the Court acknowledged that 'the consumer is not merely a spectator of the regulation of competition, but also an actor of that game, pursuing fair compensation which follows from an anti-competition act' (Lehaire 2016, 14). This was followed by the enactment of directive 2014/104 whose aim is to to 'ensure that anyone who has suffered harm caused by an infringement of competition law by an undertaking or by an association of undertakings can effectively exercise the right to claim full compensation for that harm from that undertaking or association' (directive 2014/104, art. 1).

A fourth important area of the economic antagonisms involving businesses, on one hand, and the general population, on the other, is intellectual property law, and in particular copyright law. There is a large body of EU law in this area, in particular the copyright directive (2019/790). Interpretations of this body of law are liable to impact directly upon the interests of consumers: for instance, the ECJ's UsedSoft decision legalising the second-hand market in computer program licences has had an immense impact upon consumer interests (ECJ C-128/11). Also other economic antagonisms are stake in this area of the law, such as those between small businesses, often run by individuals or families, and big multinational corporations. The case of L'Oréal v Bellure (ECJ C-487/07) is particularly instructive here. Bellure, a small producer of inexpensive 'smell-alikes', obviously destined for the poorer classes of society, used a comparative table of Bellure and L'Oréal smells, as well as alluded in the names and design of its perfumes to L'Oréal's luxury products, unavailable for its clients due to their prices. The ECJ sided with L'Oréal prohibiting Bellure from using the comparative adversiting.

Antagonisms also exist beyond economic issues, being based on conflicts of an ideological and symbolic character, including struggles for recognition and cultural wars (Mańko 2018a, 85). These kinds of antagonism enter into the orbit of ECJ jurisdiction through various channels, including the rules on the internal market freedoms and their limitations (e.g. ECJ C-159/90 Grogan concerning abortion), the free movement of citizens (e.g. ECJ C-673/16 Coman concerning same-sex marriage), or equal treatment (e.g. ECJ C-267/06 Maruko concerning same-sex partners). Ethnic minority rights, such as those concerning the spelling of a surname in one's mother tongue, also come before the ECJ (e.g. ECJ C-391/09 Wardyn).

A special place should be given to gender antagonisms, i.e. the struggle of women for equal treatment both in financial and non-financial aspects, such as access to particular jobs. An example of the first type of cases is the $V o \beta$ case (ECJ C-300/06), concerning financial discrimination of female civil servants in Germany, and of the second type of cases - the Kreil case (ECJ C-285/98) which was concerned with the right of women to serve in the army.

Apart from purely economic antagonisms (consumer/trader, employer/ employee) and symbolic antagonisms, which are often emanations of a struggle 
for recognition (minority rights, women's rights) and may have an economic component to them, there is also an emergent body of case-law concerned with specific professional groups, most notably lawyers. In this context, one can mention both cases concerned with access to the legal profession (where the antagonism is between lawyers seeking free movement vs. established lawyers in the member states, e.g. ECJ 107/83 Klopp), as well as cases concerning the struggle between judges as a professional group on one hand, and other state authorities, on the other (e.g. ECJ C-64/16; ECJ C-585/18).

So far I have focused on antagonisms which can be referred to as "horizontal" (Mańko 2018a, 85). Apart from that, there is no doubt that the ECJ solves cases which are concerned with "vertical" conflicts, concerned, in particular, with issues of primacy of EU law in confrontation with other legal orders - those of the Member States, on one hand, and those of public international law, on the other hand. However, before citing examples, it seems necessary to answer a preliminary question: can these "vertical" conflicts be indeed treated as antagonisms in the sense used in this paper? In particular, what kind of social groups or collectivities, with certain vested interests, could be identified behind the cases which established and refined the principles of supremacy, primacy or direct effect of EU law, on one hand, and the effects of international law upon the EU legal order, on the other hand? There are at least three possible answers. The first one is to focus on the "face value" of the cases, i.e. the actual litigants. In some cases, such as e.g. Francovich (ECJ C-6/90), an underlying consumer vs. business antagonism could be identified, quite apart from the national vs. supranational legal order aspects of the case. If that interpretation is followed, the case itself is treated as part of the consumer vs. business antagonism, discussed above. The second answer is to focus not on the "face value" but rather on the judges themselves. Karen Alter (2001) has shown that national judges have their own interest in supremacy and direct effect, as it empowers them vis-à-vis the national superior courts. This dimension, however, brings us back to a horizontal antagonism discussed above, namely to the professional group of judges, seeking to gain empowerment, prestige and recognition. Their opponent can be the judges of the supreme national courts or the other branches of government, and the ECJ can become their useful partner in their struggle for emancipation (Alter 2001). But we are still not close to any kind of truly "vertical" antagonism in this interpretation. In order to be able to conceptualise it, it would become necessary to treat the Court itself as a social group struggling, as such, for power and prestige vis-à-vis other centres of power, such as the legal communities of the Member States or the judges of the ECtHR. This, however, seems to go too far in the direction of watering down the very definition of antagonism. True, in terms of political science it is normal and appropriate to treat a given court as a political actor (e.g. Saurgger, Terpan 2016; Schmidt 2018, chapter 2) and analyse its interactions with other actors, such as other EU institutions or the Member States governments or national courts. However, as important as such an analysis potentially is, it goes beyond the question of the 
Court as an arbitrator of social conflicts. Hence, in conclusion, I claim that only "horizontal" conflicts can fall into the category of antagonisms. In many cases which are generally perceived as "vertical" ones because they pertain to the supremacy and autonomy of the EU legal order, a "horizontal" element can nonetheless be identified. In line with the methodology advanced here and in other papers (Mańko 2018a; Mańko, forthcoming), I consider that the concept of the political can be operationalised only with regard to the horizontal dimension. Otherwise, it loses its explanatory function by becoming dissolved in a broad universe of institutional conflicts and struggles for judicial power, with the effect of losing focus from the main issue at stake: how does the Court impact upon actual social antagonisms which are subject to its jurisdiction?

\section{CONCLUDING REMARKS}

The enterprise of adjudication belongs entirely to the field of the political (Lakomy 2019, 136), understood as the dimension of social antagonism, inherently present in the structure of every society. For judges, just like legal scholars, 'there is no escape from the political' (Mańko 2018, 33). Not only in the so-called "hard cases" but also in any case whethere there is some room for legal manouvre, requiring more or less "legal work", judges ultimately face two or more intepretive options from which to choose (Mańko, forthcoming; cf. Kennedy 1976). As a preliminary exercise to applying a critique of adjudication it is necessary to identify the dimensions of the political that are at stake with regard to a given court. This paper focused on the European Court of Justice and pointed to a number of such antagonisms, both of an economic and symbolic nature, providing examples of cases. The analysis indicates that the identification of the antagonism at stake requires to go beyond a merely formal analysis of the case at hand: the litigants need not even be represenatives of the antagonistic groups, though it is possible that they are. I have also addresed the question of so-called "vertical" antagonisms, i.e. those involving the validity and primacy of the EU legal order with regard to other legal orders, such as those of the Member States or of public international law. Keeping in mind the essential connection between the notion of an antagonism and that of a specific collectivity (group) with vested interests, which has stakes in the outcome of litigation, I concluded that such "vertical" conflicts are not per se antagonisms in the sense used in this paper, nonetheless they may conceal actual antagonisms, involving both economic conflicts (e.g. consumers/businesses) or struggles of professional groups (e.g. judges) for empowerment and recognition.

The present paper is published as part of National Science Centre (Poland) project no. 2016/21/D/HS5/03912. 


\section{BIBLIOGRAPHY}

Alter, Karen. 2001. Establishing the Supremacy of European Law: The Making of an International Rule of Law in Europe. Oxford: Oxford University Press.

Dworkin, Ronald. 1977. Taking Rights Seriously. Massachussets: Harvard University Press.

Ezrachi, Ariel. 2018. EU Competition Law Goals and the Digital Economy. BEUC Discussion Paper. https://www.beuc.eu/publications/beuc-x-2018-071_goals_of_eu_competition_law_ and_digital_economy.pdf [Accessed: 6 March 2020].

Fusco, Gian Giacomo. 2017. "Normalising sovereignty: reflections of Schmitt's notions of exception, decision and normality". Griffith Law Review 26(1): 128-146. https://doi.org/10.1080/10383 441.2017.1345708

Gray, Thomas. 2003. “Judicial Review and Legal Pragmatism”. Wake Forest Law Review 38: 473 511.

Hansen, Susan. Mark Rapley. 2006. "Group(s)”. In The Cambridge Dictionary of Sociology. 255257. Edited by Bryan C. Turner. Cambridge: Cambridge University Press.

Hesselink, Martijn. 2006. "The Politics of a European Civil Code". In The Politics of a European Civil Code. 143-170. Edited by Martijn Hesselink. The Hague: Kluwer.

Kennedy, Duncan. 2008a. "A Left/Phenomenological Critique of the Hart/Kelsen Theory of Legal Interpretation". In Legal Reasoning: Collected Essays. 154-173. Aurora: Davies Group.

Kennedy, Duncan. 2015. "The Hermeneutic of Suspicion in Contemporary American Legal Thought". Law and Critique 25(1): 91-139.

Kojève, Alexandre. 2007. An Outline of the Phenomenology of Right. Lanam: Rowman \& Littlefield.

Kukovec, Damjan. 2014. "Hierarchies as Law". Columbia Journal of European Law 21(1): 131193.

Lacan, Jacques. 1998 [1975]. The Seminar of Jacques Lacan. On Feminine Sexuality. The Limits of Love and Knowledge. Book XX: Encore. 1972-1973. Encore. Edited by Jacques-Alain Miller. Translated by Bruce Fink. London-New York: W.W. Norton.

Lehaire, Benjamin. 2016. "La protection du consommateur par le droit de la concurrence: analyse civiliste et pratique des positions canadienne et européenne". Revue internationale de droit économique 30(3): 289-313.

Mańko, Rafał. 2018a. "Orzekanie w polu polityczności”. Filozofia Publiczna i Edukacja Demokratyczna 7(1): 65-95.

Mańko, Rafał. 2018b. W stronę krytycznej filozofii orzekania. Polityczność, etyka, legitymizacja. Łódź: Wydawnictwo Uniwersytetu Łódzkiego.

Mańko, Rafał. 2018c. "Critique of the 'Juridical': Some Metatheoretical Remarks”. Journal of the University of Latvia. Law 11: 24-37.

Mańko, Rafał. Forthcoming. "The Political as an Analytical Category in the Critical Study of CaseLaw (Example of the ECJ)". Critique of Law 12(3).

Mouffe, Chantal. 2005. On the Political. Abingdon: Routledge.

Pashukanis, Evgeny. 1983. Law and Marxism: A General Theory. London: Pluto Press.

Saurugger, Sabine. Terpan, Fabien. 2016. The Court of Justice of the European Union and the Politics of Law. Red Globe Press.

Schmitt, Carl. 2005. Political Theology. Four Chapters on the Concept of Sovereignty. Chicago: The University of Chicago Press.

Schmidt, Susanne K. 2018. The European Court of Justice and the Policy Process: The Shadow of Case Law. Oxford: Oxford University Press.

Senn, Magdalena. 1999. "EU competition policy: a more holistic approach needed”. Social Europe, 28 March. https://www.socialeurope.eu/eu-competition-policy [Accesssed: 6 March 2020]. 
Šmejkal, Václav. 2015. "Competition law and the social market economy goal of the EU". International Comparative Jurisprudence 1(1): 33-43.

\section{Case law}

ECJ C-6/90. Judgment of the Court of 19 November 1991, Joined Cases C-6/90 and C-9/90, Andrea Francovich and Danila Bonifaci and others $v$ Italian Republic.

ECJ C-64/16. Judgment of the Court (Grand Chamber) of 27 February 2018, Case C-64/16, Associação Sindical dos Juizes Portugueses v Tribunal de Contas.

ECJ C-107/83. Judgment of the Court of 12 July 1984, Case 107/83, Ordre des avocats au Barreau de Paris v Onno Klopp.

ECJ C-128/11. Judgment of the Court (Grand Chamber) of 3 July 2012, Case C-128/11, UsedSoft GmbH v Oracle International Corp.

ECJ C-159/90. Judgment of the Court of 4 October 1991, Case C-159/90, The Society for the Protection of Unborn Children Ireland Ltd $v$ Stephen Grogan and others.

ECJ C-216/18 PPU. Judgment of the Court (Grand Chamber) of 25 July 2018 Artur Celmer.

ECJ C-260/18. Judgment of the European Court of Justice of 3 October 2019, Case C-260/18, Kamil Dziubak and Justyna Dziubak v Raiffeisen Bank International AG.

ECJ C-267/06. Judgment of the Court (Grand Chamber) of 1 April 2008, Case C-267/06, Tadao Maruko $v$ Versorgungsanstalt der deutschen Bühnen.

ECJ C-285/98. Judgment of the Court of 11 January 2000, Case C-285/98, Tanja Kreil v Bundesrepublik Deutschland.

ECJ C-300/06. Judgment of the Court (First Chamber) of 6 December 2007, Case C-300/06, Ursula Voß $v$ Land Berlin.

ECJ C-341/05. Judgment of the Court (Grand Chamber) of 18 December 2007, Case C-341/05, Laval un Partneri Ltd $v$ Svenska Byggnadsarbetareförbundet et al.

ECJ C-391/08. Judgment of the Court (Second Chamber) of 12 May 2011, Case C-391/08, Matgorzata Runiewicz-Wardyn and Lukasz Pawet Wardyn $v$ Vilniaus miesto savivaldybes administracija et al.

ECJ C-426/11. Judgment of the European Court of Justice of18 July 2013, Case C-426/11, Mark Alemo-Herron and Others $v$ Parkwood Leisure Ltd.

ECJ C-441/17. Judgment of the Court (Grand Chamber) of 17 April 2018, Case C-441/17, Commission $v$ Poland.

ECJ C-453/99. Judgment of the Court of 20 September 2001, Case C-453/99, Courage Ltd v Bernard Crehan and Bernard Crehan v Courage Ltd and Others.

ECJ C-487/07. Judgment of the Court (First Chamber) of 18 June 2009, Case C-487/07, L'Oréal SA et al. $v$ Bellure NV et al.

ECJ C-585/18. Judgment of the Court (Grand Chamber) of 19 November 2019, Joined Cases C-585/18, C-624/18 and C-625/18, AK v Krajowa Rada Sadownictwa.

ECJ C-673/16. Judgment of the Court (Grand Chamber) of 5 June 2018, Case C-672/16, Relu Adrian Coman and Others $v$ Inspectoratul General pentru Imigrări and Ministerul Afacerilor Interne.

SN I CSK 59/12. Judgment of the Polish Supreme Court of 6 September 2012, Case I CSK 59/12, OSNC 2013/4/51. 


\section{Rafat Mańko}

\section{WYMIARY POLITYCZNOŚCI W ORZEKANIU: STUDIUM PRZYPADKU}

Streszczenie. Wbrew tradycyjnym narracjom, wedle których orzekanie polega na stosowaniu norm prawnych do stanu faktycznego danej sprawy i nie obejmuje żadnej działalności twórczej, w niniejszym artykule wychodzi się od założenia, właściwego krytycznej teorii prawa, iż orzekanie jest praktyką społeczną należącą do sfery polityczności i zakłada podejmowanie przez sędziów decyzji. Pojęcie polityczności rozumiane jest tu - za Chantal Mouffe - jako wymiar nieusuwalnego i nieodłącznego antagonizmu, jaki leży u podstaw każdego społeczeństwa. Każde orzeczenie, a w szczególności takie, przy którego wydaniu sąd korzystał z szerokiego zakresu władzy dyskrecjonalnej, wywiera wpływ na określony antagonizm społeczny. W celu prowadzenia krytycznych badań nad orzecznictwem konieczne jest ustalenie, jaki antagonizm społeczny był $\mathrm{w}$ danym orzeczeniu istotny. $\mathrm{W}$ tym celu artykuł najpierw analizuje samo pojęcie antagonizmu, kładąc nacisk na jego zbiorowych charakter, a następnie podejmuje próbę zastosowania tego pojęcia do Europejskiego Trybunału Sprawiedliwości w celu zidentyfikowania głównych typów antagonizmów społecznych, które podlegają jurysdykcji Trybunału.

Słowa kluczowe: orzekanie, polityczność, Europejski Trybunał Sprawiedliwości. 